\title{
接近動作を伴うコミュニケーションロボットとの 交流における印象評価
}

\section{Impression evaluation on interaction with a communication robot with mobility}

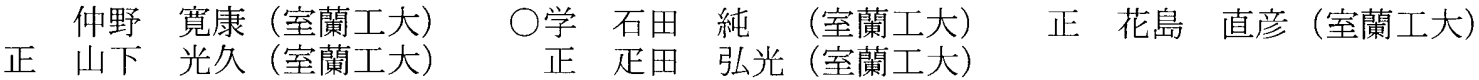

Hiroyasu NAKANO, Muroran Inst. of Tech Jun ISHIDA, Muroran Inst. of Tech

Naohiko HANAJIMA, Muroran Inst. of Tech

Mitsuhisa YAMASITA, Muroran Inst. of Tech

Hiromitsu HIKITA, Muroran Inst. of Tech

\begin{abstract}
This paper addresses impression evaluation of the communication robot from an aspect of approaching motion. From technical progress in recent years, we can expect that a robot will play an active part in our life. Coexistence of people and robots needs communication such as movement, a sound, gesture, and so on. For this reason, we build a communication robot system which play rock-paper-scissors including approaching motion. From the result of this game, we conducted the investigation and analysis of the impression which people receive from a robot.
\end{abstract}

Key Words: Robot, Interaction, Communication, Game of rock-paper-scissors, Subjective

\section{1.はじめに}

近年のロボット技術の進歩により，人がロボットと関わる機会が増 加している。、ボットの進歩は，以前から使用されていた産業ロボッ トだけはなく，ぬいぐるみロボット[1]や腕·視線を用いるロボット[2] といった人とのコミュニケーションを行うロボットの実現を目指し た研究が行われている. また, これらコミュニケーションロボットは, 機械的な性能のみならず, 人間の心理的な評価も考慮される必要があ り, 現在研究汃進んでいる[3].

我々の過去の研究では，ベイジアンネットワーク(BN:Bayesian Network)をもちい，人とのコミュニケーションの中から好印象を与え る動作を学習するロボット[4]について研究を行った.

本研究では，コミュニケーションロボットの接近動作の違いに着目 し，ロボットが移動する場合とそうでない場合のジャンケンゲームを 通したコミュニケーションから，人がロボットに対してどのような印 象を持つかを主観調查により調べ，解析する.

\section{2. コミュニケーションロボット}

\section{1 コミュニケーションロボット概要}

図 1 と図 2 は, 研究に用いたコミュニケーションロボットである. コミュニケーションロボットは, ボブィ, ロボットアーム, 移動台車, 測域センサなどにより構成されている.

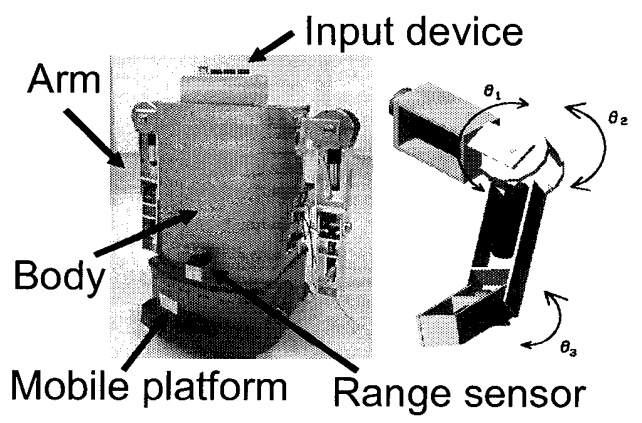

Fig.1 Overview of communication robot (Left: Whole image, Right: Robot arm)

\section{2 コミュニケーションロボットの各システム}

\section{2.1 測域センサ}

測域センサとは，レーザを照射し距離を測るセンサである。 今回使用した「URG-04LN(北洋電機株式会社製)」は，照射部分を回 転させ対象物までの距離と方向を取得し，二次元的な距離データを取 得している. 測定距离隹範囲 $4 \mathrm{~m}$, 測定範囲 $270^{\circ}$, 走查時間 $100 \mathrm{~ms} / \mathrm{scan}$, 角度分解能 $360^{\circ} / 1024$, PC との通信は USB と RS-232C, 質量 $160 \mathrm{~g}$ である.

\subsection{2 移動台車}

移動台車には独立 2 輪型移動ロボット「LABO-3(Applied AI Systems 社製)」を採用している. リアルポートを用いPC との通信が可能で, あらかじめ移動速度や車輪回転方向などを設定しておき，LABO-3 を 制御することが可能である.

\subsection{3ボディ}

ボディは，(株)ミスミの縦 $20 \mathrm{~mm}$ ，横 $20 \mathrm{~mm}$ のアルミフレームよ り組み上げている. ボディ内部は上段にロボットアーム肩部のモータ とシャフト，中段にドライバとコントローラ，パーソナルコンピュー タ，下段にバッテリーを搭載している.

\section{2.4 ロボットアーム}

ロボットアームは，人の腕を模した 3 自由度(図 1 右)で, 肩から肘 が $25 \mathrm{~cm}$, 肘から腕の先が $20 \mathrm{~cm}$ ある. 図 1 右のように関節が駆動する. また，1つのアームの重量は約 $3 \mathrm{~kg}$ である.

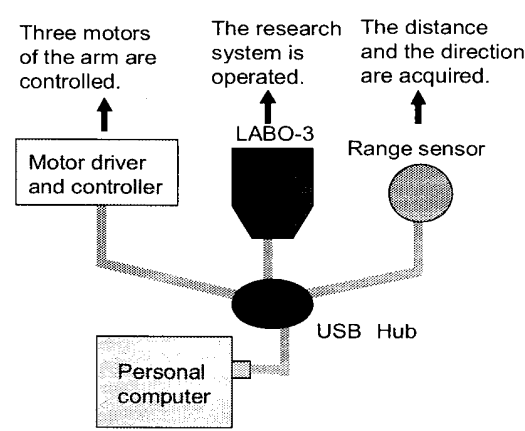

Fig.2 Control scheme of communication robot 


\section{3. ロボットの提示動作}

\section{1 ロボットの動作環境}

ロボットの動作環境を上から見ると図 3 のようになっている. ロボ ットは Left, Middle, Rightのいずれかから出発して, Stop の位置ま で移動する．これを接近ありの条件とする．接近なしの条件では，移 動させずに初めから Stop の位置から始める. 次に, あらかじめ録音し たロボットの発する声(女性の声)に合わせてじやんけんをする. じゃ んけんは 3 回で1セットとする.ロボットのプログラムのフローチヤ 一トは図4のようになっている. 以下フローチャートの説明をする.

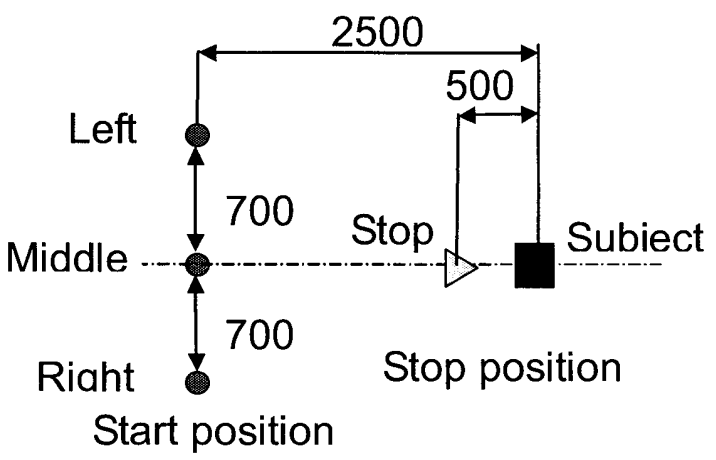

Fig.3 Topview of experimental environment

\section{2 測域センサによるセンシング 1 回目}

本研究で用いたコミュニケーションロボットは, 測域センサが人の 脚を検出することによって人の位置を判断している．ただし，実験空 間には被験者しか存在せず，コミュニケーションロボット動作開始位 置と被験者の位置が図 3 のようにほほ確定しており，その距離は約 $2500 \mathrm{~mm}$ である.このため, 図4のように 1 回目のセンシング時には, $1500 \mathrm{~mm} \sim 3000 \mathrm{~mm}$ の範网内に距離データが存在するとき，その距離 データと方向データを採用データとして別に保存する.この抽出を検 出範用全てに行うことで採用データ群を作成寸る. 採用データ群の距 離データと方向データの算術平均をそれぞれ人までの平均距離, 平均 方向とする.

\section{3 測域センサによるセンシング 2 回目以降}

測域センサの走査時間が一周 $100 \mathrm{~ms}$ と高速であるため, 次の測定 までに人は大きく移動しないものと考え，2 回目以降のセンシングで は, 前回のセンシング時に求められた平均距離の $\pm 100 \mathrm{~mm}$ を採用デ 一夕範囲としてデータの選定を行う．人の足までの距離が $500 \mathrm{~mm}$ 以 下になったら，停止命令を送信し接近を終了寸る.

\section{4 平均距離が $500 \mathrm{~mm}$ 以下}

次に, 平均距離が, $500 \mathrm{~mm}$ 以下になった時に平均方向が $87^{\circ} \sim 93^{\circ}$ の範用であるか判定し，この範用に入るように移動台車に動作指令を 送信し方向を変化させる.これにより，コミュニケーションロボット の正面が，被験者を向いた状態で停止する．ただし，ロボットの正面 と被験者の正面が向き合うとは限らない．

\section{5 LABO-3 への移動命令}

移動台車は，測域センサにより求められた平均距離と平均方向に対 灾して左右の車輪の動作力向と速度を変化させる. あらかじめ $\mathrm{PC} に$ 左右それぞれの車輪の動作方向と速度のパターンをデーブルに設定 しておき，場面に応じてテーブルを参照して命令を移動台車に送信寸 ることで移動台車を制御している.たとえば，コミュニケーションロ ボットと被験者との距離が遠いときはスピードを上げる，ロボットが 人の方向を向いていないときは人の方を向くなどである.

\section{6 ジャンケンゲーム}

移動台車の接近によりコミュニケーションロボットが被験者の約 $500 \mathrm{~mm}$ 手前に接近した後に音声誘導を伴いながらジャンケンゲーム を行う. 初めロボットアームは，腕の先を床に向けた状態である。ロ ボットが音声で「じやん・けん・ぽん」と言った後, 被験者が押しボ タンを使い手役を入力する. 被験者がスイッチを押守すぐにロボッ トアームが動き手役を出し(手役: 図 5)動作が完了する. ロボットア 一ムは安全性を考慮して, 動作を遅く設定してあるため, 被験者がボ タンを押してからロボットアームの動作が終了するまで数秒間かか る. ジャンケンの勝敗については, コミュニケーションロボットが音 声で知らせてくれる.このジャンケンを 3 回行うことを 1 ゲームとし ている.

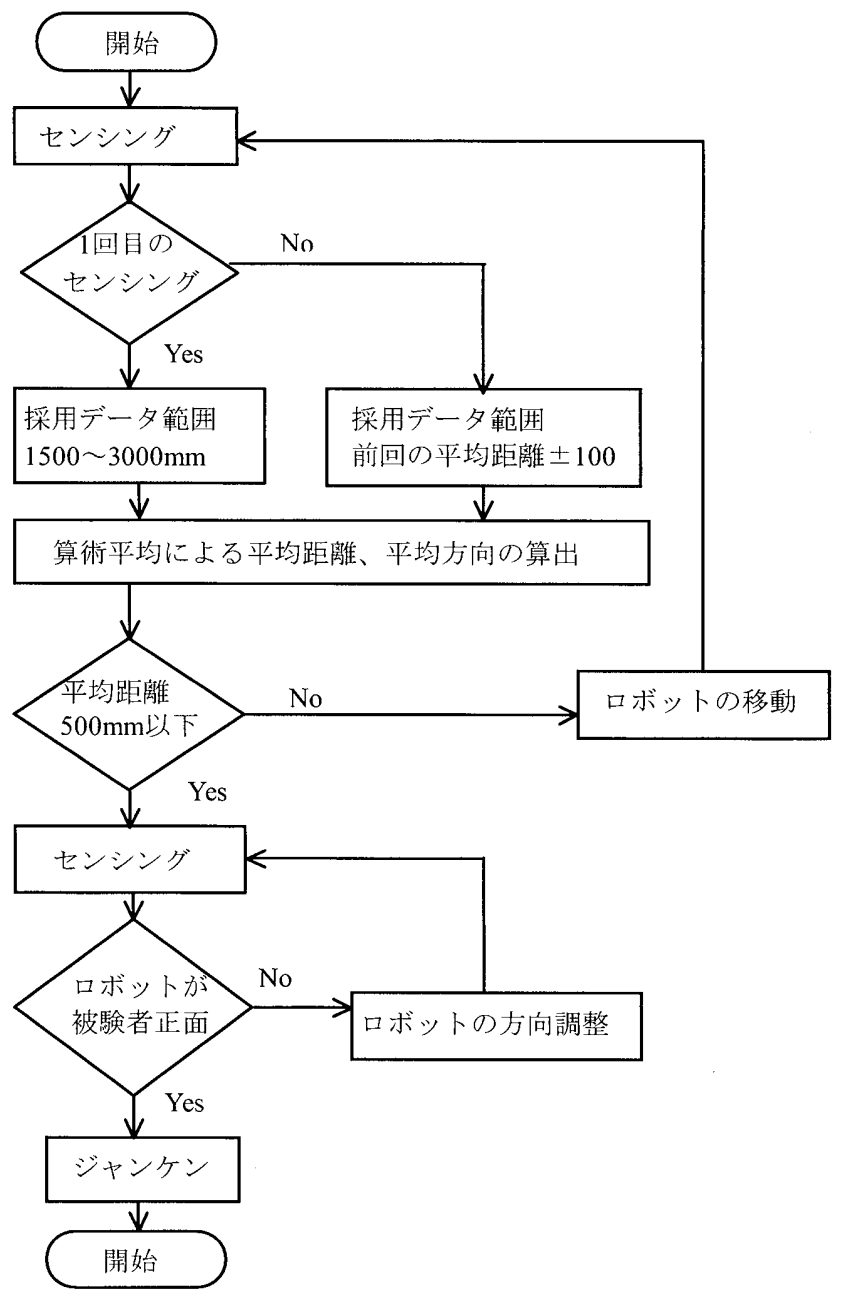

Fig.4 Flow chart

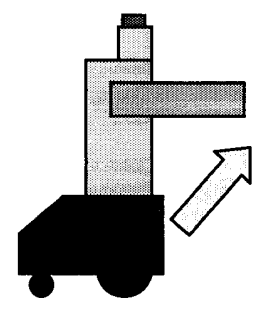

Side view

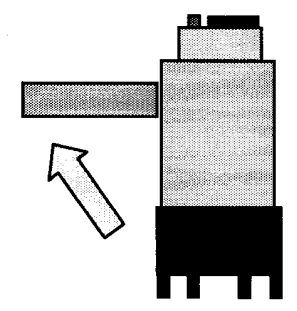

Front view

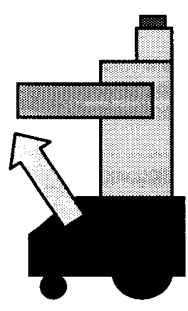

Side view
Fig.5 A game of rock-paper-scissors (Left: rock, Middle: paper, Right: scissors) 


\section{4. 接近動作に着目した心理的評価実験}

\section{1 实験方法}

被験者は,インフォームドコンセントを行った 7 49歳の男性 11 名,女 性 5 名の計 16 名である. 実験は，1 人ずつ行ない，被験者はイスに 楽な姿勢で座ってもらう(位置: 図3の Subject).. 被験者に, 被験者が 出す手役に対応するスイッチ及び，ロボットの出寸手役に対応寸るア 一ムの動き(図 5)を確認してもらう。確認後, ランダムに実験条件か ら1つを選択し,䒠験条件を変えて前節のジャンケンを 3 回ずつ行う。 各条件が終了するごとに毎回,被験者は 14 形容詞対から構成された SD法の質問用紙に回答寸る。

\section{5. 実験結果·考察}

\section{1 平均値からの田象評価}

16 名の被験者の 14 形容詞対を用いた SD 法による主観郭価が得ら れた. 各形容詞刘についての7段階尺度 $(3,2,1,0,1,2,3)$ の設定をポジ ティブな形容詞側が高くなるように 1 から 7 まで数值化した.

図6は,接近なしと接近ありの場合における各形容詞対の平均值の プロットである。「安心な「好き」愉快な」などで，高い值になつ ていることから，ロボットの動作は，被験者に対して好意的な印象を 与えていることが分かる. 接近なしと接近ありの平均值の変化形状は， ほぼ同様の変化を示している.これにより，接近動作を加えることで の人の受ける印象は，さほど变化しないと分かる．また，「速い，遅 いと「派手な，地味な」の2つの形容詞対の平均值が，他の值より も低めである。これは，実験中に批る何除性を考慮しコミュニケー ションロボットの移動速度を減少させたことと, 機器の接続状態を隠 すためにプラスチックカバーを付けていたため，ロボットが地味に見 えたためであると考えられる.

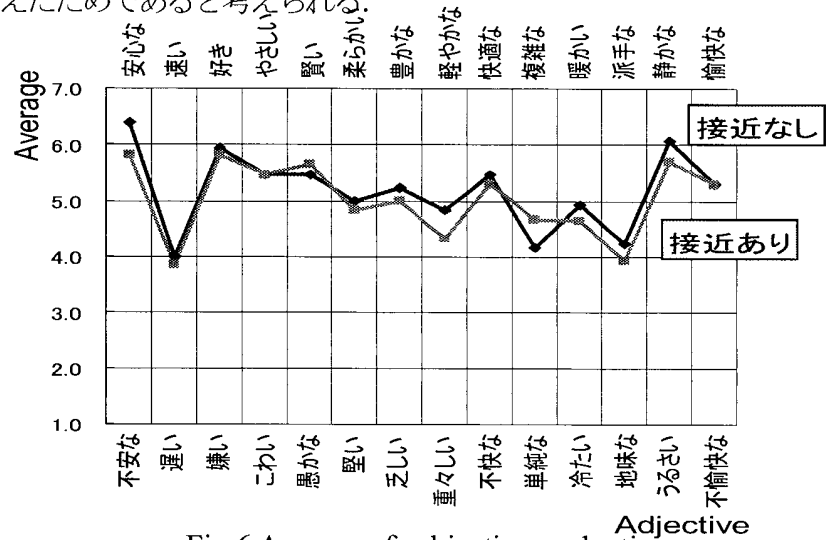

Fig.6 Average of subjective evaluation

\section{2 主钼評洒による因子分析}

形容詞対をいくつかの因子にまとめるため, 主観評価デー夕の因子 分析を行った. 因子分析に関するクロンバックの $\alpha$ 信頼性係数は 0.929 であり,因子分析に問題無い水淮であるといえる. 反復主因子法 より共通性の初期值 1 と仮定し,バリマックス回転を採用した結果, 固 有值が 1 以上である 3 因子が得られた。表 1 亿因子負荷量を示高。第 1 因子は軽やかな」豊かな」柔らか心「好き」などの負荷量の大 きさが負の方に高かった．そこでこの因子はロボットの機械的な 重々しい動きが嫌要感を与えたと解釈し「嫌悪性了因子と名付けた。第 2 因子は暖か心り「愉快な」などの負荷量が高かったので，被験者自 身の快，不快に基づく情緒的な評価を行っていると解䣋し「親近性」 因子と名付けた. 第 3 因子は派手な，複雑な小ざの負荷量が謞か力 た.そこで, ロボットの動作の多様性に関わると解积し，「多樣性」因子 と名付けた，図 7 は，実験条件ごとの因子得点による箱しけ四である。 また,バーレット検定により全ての因子は有意水淮 $5 \%$ て等分散性が 認如られた。の結果より，各因子の検定に一元配置分散分析を用いた。
Table 1 Factor loading after varimax rotation

\begin{tabular}{|c|c|c|c|c|c|}
\hline No. & 形容詞対 & 嫌悪性 & 親近性 & 多様性 & 共通性 \\
\hline 8 & 軽やかな・重々しい & -0.894 & 0.222 & 0.006 & 0.849 \\
\hline 7 & 豊かな・乏しい & -0.871 & 0.279 & 0.071 & 0.842 \\
\hline 6 & 柔らかい・堅い & -0.864 & 0.398 & -0.013 & 0.904 \\
\hline 9 & 快適な・不快な & -0.830 & 0.211 & 0.107 & 0.745 \\
\hline 2 & 速い・遅い & -0.706 & 0.133 & 0.257 & 0.583 \\
\hline 1 & 安心な・不安な & -0.683 & 0.464 & -0.091 & 0.69 \\
\hline 4 & やさしい・こわい & -0.657 & 0.617 & -0.049 & 0.814 \\
\hline 3 & 好き・嫌い & -0.625 & 0.534 & -0.127 & 0.693 \\
\hline 5 & 賢い・愚かな & -0.566 & 0.553 & -0.076 & 0.632 \\
\hline 11 & 暖かい・冷たい & -0.534 & 0.691 & 0.226 & 0.814 \\
\hline 14 & 愉快な・不愉快な & -0.351 & 0.689 & 0.004 & 0.598 \\
\hline 13 & 静かな・らるさい & -0.028 & 0.463 & 0.149 & 0.237 \\
\hline 12 & 派手な・地味な & -0.308 & 0.075 & 0.730 & 0.626 \\
\hline \multirow[t]{4}{*}{10} & 複雑な・単純な & 0.133 & 0.058 & 0.659 & 0.463 \\
\hline & 因子負荷量の二乗和 & $\overline{5.62}$ & 2.71 & 1.16 & \\
\hline & 寄与率 & 40.17 & 19.36 & 8.26 & \\
\hline & 累積寄与率 & 40.17 & 59.53 & 67.79 & \\
\hline
\end{tabular}
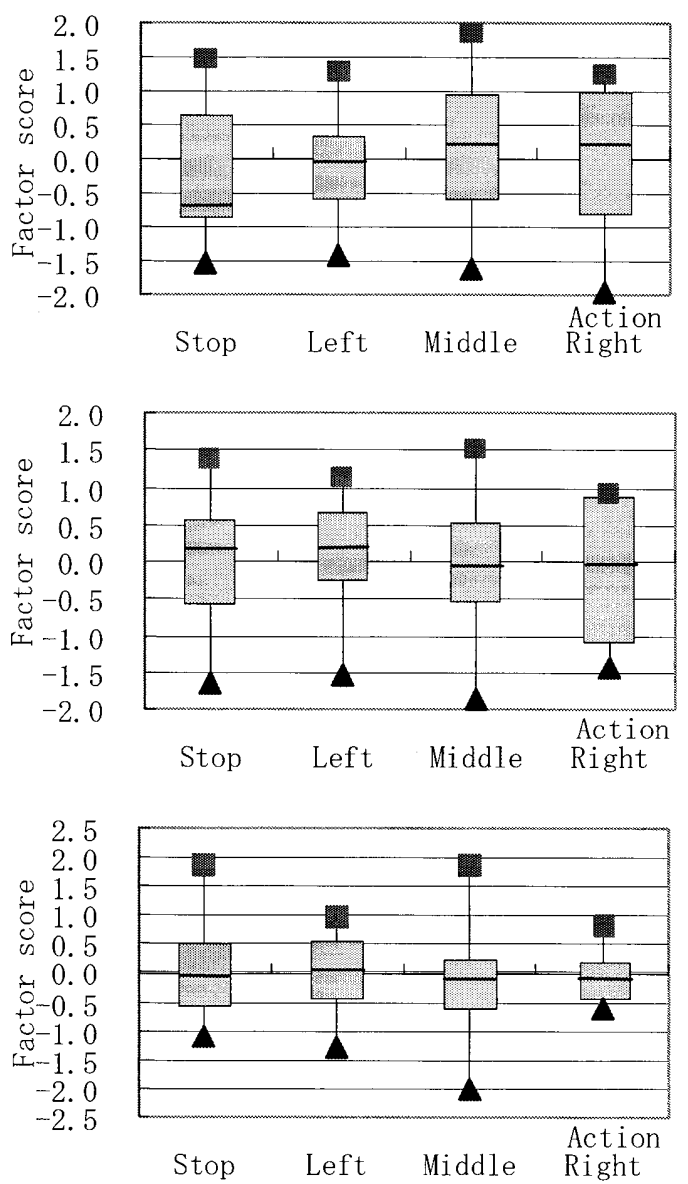

Fig.7 Box-and-whisker plots (Upper Center : Factor I,

Under left : Factor II, Under right : FactorIII )

検定の結果，各因子とも有意水準 5\%で平均值に有意差がないとされ た.これらより，ロボットの移動条件を変化させることで人の印象に 影響を与えるほどの有意差を導き出すことができないことが分かっ た.これは，実験条件の違いが少な寸ぎたことなどが考えられる。し かし, 図 7 の嫌悪性因子(Factor I)では，平均值を比較すると Stop は それ以外に比べて中央值がやや小さいことが分かる。 これより，接近 動作が人に多少なりとも嫌悪感を与えたものと読みとれる. 


\section{3 接近時と静止時の差異に関する分析}

次に, 接近無しの静止時の評定值を基淮にして，接近時の評定値と の差異を求め, これを形容詞対ごとに分析する.この差を評定差と呼 ぶことにする. 接近時の評定值が大きいときに，評定差が正となるよ うにした．評定值は被験者間でかなりばらつきがあるが，評定差を計 算することで，ある程度ばらつきを抑えられる。

全ての被験者のうち静止時の実験を行つたのは 13 名であった。こ れらの被験者は接近時の実験を 2 回行っているので, 評定差のデータ は 1 名につき 2 件となる. したがって形容詞対ごとに 26 の評定差デ 一タが得られた。

図 8 にこれらの箱ひげ図を示す．「安心な，不安な」など 6 つの形 容詞対で0付近に密に分布している. それ以外の8つの形容詞ついて, 評定差の平均值が 0 に等しいという帰無仮説に対して $\mathrm{t}$ 検定を行った。 表 2 に 8 形容詞対におうる, 評定差の平均值, $\mathrm{t}$ 值, 両側検定の $\mathrm{p}$ 值 を示寸。

有意水淮 5\%で差があったのは，「暖かい，冷たい」の形容詞対であ る. この評定差の平均值は負であることから，接近時の方が静止時よ りも冷たい印象を与える傾向があるといえる．この傾向は図6の評定 值全体の平均值のグラフにも表れている. 実験前の仮説では「近寄る」 という行動が被験者に親しみを与えると考えていたが，逆の印象とな っていたようである. ロボットの接近動作の様子が機械的な印象を与 えたか，じやんけんの結果などの別の要因が働いたためかもしれない この他には「賢い，おろかな」「派手な，地味な」においてやや有 意差がみられる. 評定差の平均值から，接近時の方が静止時よりもや や賢く, やや地味な印象を与える傾向があると読み取れる. 接近時は, 測域センサで被験者のいる力向を探して近づくという動作が加わる ので，接近動作がないよりはより賢い印象を与えたと解釈できる。 そ ういう意味では，接近時の方が動作は派手な印象を与えそうであるが， 逆にやや地未な印象を与えたようである. これはロボットの移動速度 が遅かったせいか，じやんけんなどの別の要因が働、たためかもしれ ない.

今回の実験では，人とロボットのコミュニケーションが行われる状 況下での, 接近動作の有無による印象の違いを調べるのが目的であつ たが，被験者は口ボットとのじやんけんにも注意を向けていたようで ある. 実際，質問紙の自由記述欄には，何件かじやんけんゲームに対 するコメントが書かれていた。 接近動作の有無は印象の違いを与え ていたはずであるが, 形容詞対によっては，接近動作よりもむしろじ やんけんのタスクが主に評価されていたことも考えられる.また，評 価のタイミングがじやんけんの直後だったので, 評価か接近動作より もじやんけんに引きずられた可能性もある.
Table 2 Result of $t$ test for difference of rating values between approaching and motionless

\begin{tabular}{|c|c|c|c|}
\hline $\begin{array}{c}\text { adjective } \\
\text { (positive) }\end{array}$ & mean & $\mathrm{t}$ value & $\mathrm{p}$ value \\
\hline 速い & -0.038 & -0.16 & 0.88 \\
\hline やさしい & 0.23 & 1.2 & 0.23 \\
\hline 賢い & 0.42 & 1.7 & 0.094 \\
\hline 豊かな & -0.12 & -0.62 & 0.54 \\
\hline 複雑な & 0.12 & 0.46 & 0.65 \\
\hline 暖か心 & -0.35 & -3.1 & 0.0043 \\
\hline 派手な & -0.31 & -1.9 & 0.073 \\
\hline 静かな & -0.19 & -0.63 & 0.53 \\
\hline
\end{tabular}

\section{6. おわりに}

本研究では動作に接近を加えることにより人がロボットから受け る印象を調査し,考察を行った. 因子分析により 3 つ因子を抽出する ことができた. また，実験条件の違いにより平均值の有意差が湿著で は無かったが，全体的に好意的な印象を与えていた. さらに評定差に つい考慮すると，接近時の方が静止時よりも「冷たい」「地味な」 などの印象を与えている傾向があった。これは，ロボットの速度や実 験状況が原因とも考えられ，どのような場合でもロボットの接近動作 が人に対して不快に感じさせるかは，今後の実験でさらに詳しく調べ る必要があると考えられる.

\section{考文献}

[1]柴田崇徳：“人とロボットの身体的インタラクションを通した主観 的価值の創造一アザラシ型メンタルコミットロボットの研究開発一”, 日本ロボット学会誌, Vol.18, No2, pp200-203, 2000.

[2]G.Cheng and Y.Kuniyoshi: "Complex Continuous Meaningful Humanoid Interaction: A Multi Sensory-Cue Based Approach,"Proc. IEEE International Conference on Robotics and Automation, Volume 3, pp.2235-2242, 2000.

[3]神田崇行，石黒浩，石田亨：”人間-ロボット間相互作用に関わる心 理学的評価”, 日本ロボット学会誌, Vol.19, No.3, pp.362-371, 2001

[4]山下航平, 花島直彦, 山下光久, 疋田弘光 : ”インタラクションロボ ットへの BN ベース内部モデルの適用”, 日本機械学会, ロボティク ス・メカトロニクス部門講演会107，2P1-F01， 2007

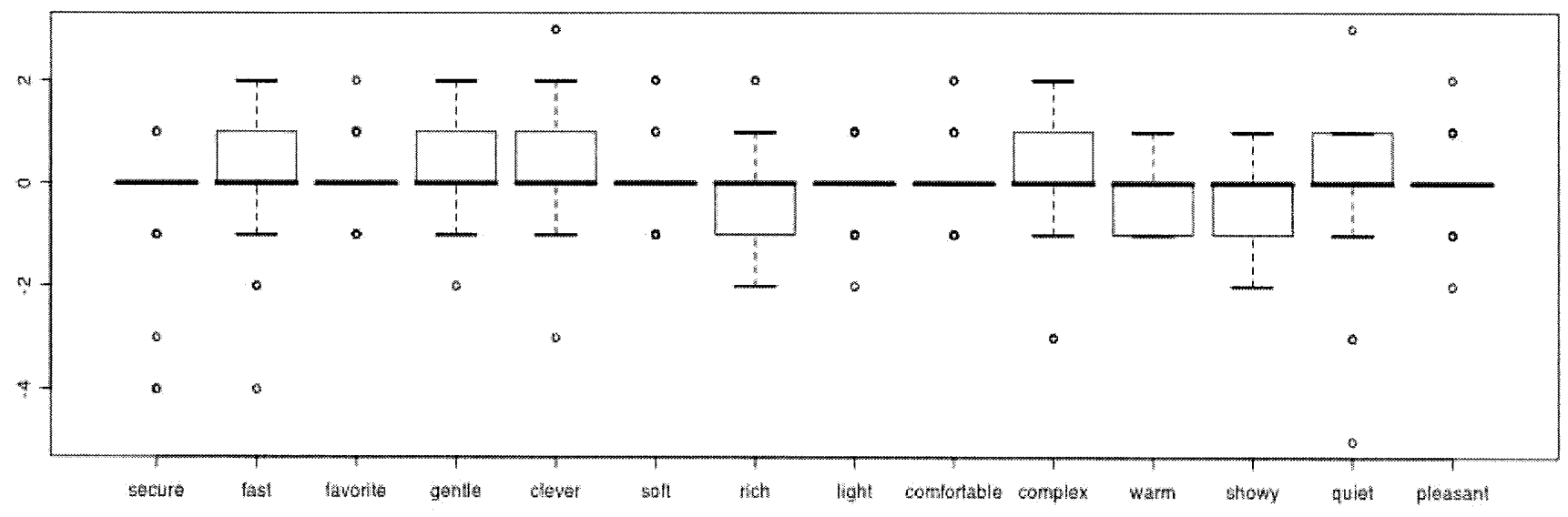

Fig. 8 Boxplot of rating differences for each adjective pairs 